\title{
Metabolic and oxidative status of West African dwarf does at different reproductive stages in southwest Nigeria
}

\author{
Abubakar Olatunji Jimoh ${ }^{1,2^{*}}$ (D, Olayinka Abosede Ojo ${ }^{2,3}$ and Uchechi Daureen Gift Ihejirika ${ }^{2}$
}

\begin{abstract}
Background: A study was conducted to investigate changes in oxidative stress indicators of West African dwarf (WAD) goats at different reproductive stages. There are a total of 35 dry does, 30 gravid does at first trimester (4045 days post-mating), 33 gravid does at second trimester (85-90 days post-mating), 31 gravid does at third trimester (135-140 days post-mating), and 40 postpartum does (30-35 days postpartum). Fastened blood samples were collected from all tagged animals and serum obtained. Serum was assayed for lipid peroxidation, total antioxidant activity, glutathione peroxidase, catalase and superoxide dismutase, serum biochemical, glucose, total protein, albumin, cholesterol, triglyceride, high-density lipoprotein, alkaline phosphatase, alanine aminotransferase, aspartate aminotransferase, urea, and creatinine using standard procedures.

Results: Result revealed that intense metabolic changes were associated with late prepartum and postpartum does as pronounced in oxidative and biochemical indicators of WAD does. Significant differences were found in serum biochemical indices across the different physiological stages of the doe except for triglyceride and low-density lipoprotein. Antioxidant defense is higher at early and mid-gestation and dry does, through low lipid peroxidation and high antioxidant activity as compared to late gestation and lactation does.
\end{abstract}

Conclusion: The observed result shows that the WAD does display oxidative stress during late gestation and lactation owing to intense metabolism. Antioxidant fortification should be employed especially during late gestation and lactation to counteract the oxidative stress in WAD goats.

Keywords: Antioxidant, Gravid, Lipid peroxides, Postpartum, Serology

\section{Background}

The West African dwarf (WAD) goats are found in the region south of latitude $14^{\circ} \mathrm{N}$ across West Africa in the coastal area, which is humid and favors high prevalence of diseases. West African dwarf goats are found in the ecozone infested with tsetse fly, thrive well, and contribute in part to the meat requirement in this region (Adeloye 1998). The harsh environmental conditions of the tropics in which the animals are exposed to are further aggravated by the seasonal fluctuations in quantity and quality of most of the feed resources which they

\footnotetext{
* Correspondence: abubakarjimoh2011@gmail.com

${ }^{1}$ Animal Production Unit, Department of Agricultural Technology, Federal

Polytechnic Ado-Ekiti, Ado Ekiti, Ekiti State, Nigeria

${ }^{2}$ Animal Physiology and Bioclimatology Unit, Department of Animal Science,

University of Ibadan, Ibadan, Oyo State, Nigeria

Full list of author information is available at the end of the article
}

depend on, may aggravate, or have negative consequences on the overall well-being of the animal (Jimoh et al. 2018).

Oxidative stress is a budding field of research in ruminant medicine and has been implicated in numerous diseases including sepsis, mastitis, acidosis, ketosis, enteritis, pneumonia, and respiratory and joint diseases. Compared to human medicine, only a limited number of physiological status have been investigated with regard to the effects of oxidative stress in ruminants (Celi 2011a). Jack et al. (2016) suggested the relevance of periodic assessment of oxidative status in ruminants for healthier management and supplementation of antioxidants as supportive treatment of diseases such as peste des petits ruminants (PPR). Ihejirika et al. (2017) reported emphasis should be on antioxidant activity of does with different physiological stages, so as to improve 
productivity. Some production function that has high physiological demand includes pregnancy, and lactation has reported to lead to oxidative stress in animals and human. Increased free radical production arises from increased metabolic activity, negative energy balance and ketone body formation, reduction of antioxidant reserve, exhaustion of the antioxidant defense system, metabolic acidosis during pregnancy, and physiologic adaptation of pregnant animals to lactation (Al-Qudah 2011). The ovary has long been recognized as a site of ascorbic acid accumulation, which is probably due to the high rates of tissue remodeling and collagen synthesis that is required for follicular growth, for repair of the ovulated follicle, and for corpus luteum development and steroidogenesis (Luck et al. 1995). It has been hypothesized that antioxidants and oxidative stress may influence the timing and maintenance of a viable pregnancy as threshold levels of female oxidative stress exist, depending on anatomic location and stage of preconception (Ruder et al. 2008). Also, notable is the cellular origin of oxygen radicals in corpora lutea from resident and infiltrated leukocytes may lead to the risk of ovarian pathology which may be exacerbated under the condition of reduced antioxidant status (Behrman et al. 2001).

In spite of the harsh environment coupled with fluctuations in quality and quantity of feed resources, West African dwarf goats are important to meet the animal protein demand of the region. It is important to establish appropriate physiological baseline values for WAD does at different physiological stages which could be used in the realistic evaluation of the management practice, nutrition, and diagnosis of the prevailing health condition. There are few reports on the oxidative status of West African dwarf goats, amidst calls for research focus on the establishment of a reference panel of the biomarker of oxidative stress to be used in ruminant medicine (Celi 2011b). This study aims to document the baseline range of oxidative stress markers and requirements for antioxidant defense at different physiological stages of West African dwarf does.

\section{Material and methods}

\section{Experimental site and animal management}

The study was conducted on a livestock farm located in Ikere Ekiti, southwest Nigeria. The study spanned from April to September 2017. There were a total of 169 healthy West African dwarf ewes, 2-4 years old, and with an average body weight $(15.34 \pm 4.92)$ and body condition between 2.5 and 3.5. Body condition score (BCS), usually a visual assessment of the amount of fat and muscle covering the bones of a goat, evaluates fatness or thinness according to a 5-point scale, where BCS 1 -very thin, BCS 2-thin, BCS 3 -good condition, BCS 4-fat, and BCS 5-obese (Ockert 2015). The selected does were tagged on their right ear for easy recognition among the whole flock (237 does). The research was approved by the institution's research ethics committee for care and use of animals for research. The does were managed in a semi-intensive system, which employed batch mating (estrus synchronization and artificial insemination), and non-return to estrus was used to confirm conception. Information from farm breeding record was utilized to categorize the physiological state of the does. The treatments consist of 35 dry does, 30 gravid does in the first trimester (40-45 days post-mating), 33 gravid does in the second trimester (85-90 days postmating), 31 gravid does in the third trimester (135-140 days post-mating), and 40 postpartum does (30-35 days postpartum). Goats were allowed to graze on natural pasture from 07:30 to 17:30 and kept in pens from 17:30 to $07: 30$ during the trial. Freshwater was available ad libitum. Concentrate supplement was offered in the pen; it had $12.6 \%$ crude protein, $10.0 \%$ crude fiber, and 3202 $\mathrm{kcal} / \mathrm{kg}$ of digestible energy. Kids were not weaned, and goats were not milked throughout the lactation period. The management of the goat did not change during the experimental period.

\section{Sample collection and analysis}

Fastened blood samples were collected from all tagged does once between 07:00 and 08:00 in their pens. The blood samples were taken from Vena jugularis between July and August when the climate conditions are not supposed to increase the production of reactive oxygen species because of heat stress (Jimoh 2016 and Jimoh and Ewuola 2018). Blood sampling was done across all breeding stages at each sampling date by randomly selecting animals, and tags of sampled animals were recorded to prevent repeated sampling. The samples were taken into $10 \mathrm{~mL}$ plain tubes and were centrifuged for $10 \mathrm{~min}$ at $3000 \mathrm{rpm}$. Serum samples were kept at $-20^{\circ} \mathrm{C}$ until the analysis which were carried out in batches within 7 days.

\section{Estimation of serum biochemical and oxidative stress indicators}

Serum biochemical, glucose, total protein, albumin, cholesterol, triglyceride, high-density lipoprotein, alkaline phosphatase, alanine aminotransferase, aspartate aminotransferase, urea, and creatinine were carried out using Randox kits and its procedures. Serum was assayed for lipid peroxidation, glutathione peroxidase, catalase, superoxide dismutase, and total antioxidant which were carried out as outlined by Jimoh (2019).

Determination of serum total antioxidant capacity was carried out according to Korecevic et al. (2001). The reactive mixture contained $0.5 \mathrm{~mL}$ of $\mathrm{Na}$-Benzoate $(10$ $\mathrm{mmol} / \mathrm{L}), \quad 0.2 \mathrm{~mL}$ of $\mathrm{H}_{2} \mathrm{O}_{2}(10 \mathrm{mmol} / \mathrm{L}), 0.49 \mathrm{~mL}$ of 
phosphate buffer $(100 \mathrm{mmol} / \mathrm{L}, \mathrm{pH}=7.4)$ (prepared by mixing $19.5 \mathrm{~mL}$ of $\mathrm{KH}_{2} \mathrm{PO}_{4}(100 \mathrm{mmol} / \mathrm{L})$ with $80.5 \mathrm{~mL}$ of $\mathrm{Na}_{2} \mathrm{HPO}_{4}(100 \mathrm{mmol} / \mathrm{L})$, then adjusted the $\mathrm{pH}$ to 7.4$)$, and $0.2 \mathrm{~mL}$ of Fe-EDTA complex $(2 \mathrm{mmol} / \mathrm{L})$ (this was freshly prepared by mixing equal volumes of EDTA (2 $\mathrm{mmol} / \mathrm{L})$ and ammonium ferrous sulfate $(2 \mathrm{mmol} / \mathrm{L})$ and left to stand at $25^{\circ} \mathrm{C}$ for $\left.60 \mathrm{~min}\right)$. Ten microliters of the serum was added to the latter reactive mixture and was incubated at $37^{\circ} \mathrm{C}$ for $60 \mathrm{~min}$. Finally, $1 \mathrm{~mL}$ glacial acetic acid $(20 \mathrm{mmol} / \mathrm{L})$ and $1 \mathrm{~mL}$ thiobarbituric acid $(0.8 \% \mathrm{w} / \mathrm{v}$ in $100 \mathrm{~mL}$ of $50 \mathrm{mmol} / \mathrm{L} \mathrm{NaOH}$ ) were added, and the absorbance at $532 \mathrm{~nm}$ was measured spectrophotometrically after incubation at $100{ }^{\circ} \mathrm{C}$ for $10 \mathrm{~min}$. Total antioxidant capacity was calculated according to the following formula:

Total antioxidant capacity $(\mathrm{mmol} / \mathrm{L})=(\mathrm{CUA})(\mathrm{K}-$ A)/(K - UA)

where

CUA is the concentration of uric acid ( $\mathrm{mmol} / \mathrm{L}$ )

$\mathrm{K}$ is the absorbance of control (K1 - K0)

$\mathrm{A}$ is the absorbance of the sample (A1 - A0)

UA is the absorbance of uric acid solution (UA1 UA0)

Superoxide dismutase (SOD) activity was estimated by the method of Soon and Tan (2002) by adding $2.1 \mathrm{~mL}$ of $50 \mathrm{mM}$ buffer, $0.02 \mathrm{~mL}$ of enzyme source, and $0.86 \mathrm{~mL}$ of distilled water. The reaction is initiated with $0.02 \mathrm{~mL}$ of $10 \mathrm{mM}$ pyrogallol and change in absorbance monitored at $420 \mathrm{~nm}$. One unit of SOD is defined as the amount of enzyme required to inhibit the auto-oxidation of pyrogallol by $50 \%$ in a standard assay system of $3 \mathrm{~mL}$. The specific activity is expressed as units $/ \mathrm{min} / \mathrm{mg}$ protein.

Glutathione peroxidase activity (GPx) was estimated as described by Rotruck et al. (1973), by adding $0.5 \mathrm{~mL} 0.4$ $\mathrm{M}$ buffer (pH 7.0), $0.2 \mathrm{~mL}$ enzyme source, $0.2 \mathrm{~mL} 2 \mathrm{mM}$ $\mathrm{GSH}$, and $0.1 \mathrm{~mL} 0.2 \mathrm{mM} \mathrm{H}_{2} \mathrm{O}_{2}$, and incubated at room temperature for $10 \mathrm{~min}$ along with a control tube containing all reagents except enzyme source. The reaction was arrested by adding $0.5 \mathrm{~mL}$ of $10 \%$ TCA and centrifuged at $4000 \mathrm{rpm}$ for $5 \mathrm{~min}$, and the GSH content in $0.5 \mathrm{~mL}$ of supernatant was estimated. The activity was expressed as microgram of GSH consumed $/ \mathrm{min} / \mathrm{mg}$ protein.

Catalase activity assay system contains $1.9 \mathrm{~mL} 0.05 \mathrm{M}$ buffer (pH 7.0) and $1.0 \mathrm{~mL} 0.059 \mathrm{M} \mathrm{H}_{2} \mathrm{O}_{2}$. The reaction is initiated by addition of $0.1 \mathrm{~mL}$ enzyme source. The decrease in absorbance is monitored at $1 \mathrm{~min}$ interval for $5 \mathrm{~min}$ at $240 \mathrm{~nm}$, and activity is expressed as nanomoles of $\mathrm{H}_{2} \mathrm{O}_{2}$ decomposed $/ \mathrm{min} / \mathrm{mg}$ protein, estimated by Beers and Sizer (1952) method.

Serum lipid peroxidation was determined according to Ohkawa et al. (1979); the reaction mixture in a total volume of $3.0 \mathrm{~mL}$ contained $1.0 \mathrm{~mL}$ serum and $1.0 \mathrm{~mL}$ of
TCA $(0.67 \%)$. All the test tubes were placed in a boiling water bath for a period of $45 \mathrm{~min}$. The tubes were shifted to the ice bath and then centrifuged at $2500 \mathrm{rpm}$ for 10 min. The amount of malondialdehyde (MDA) formed in each of the samples was assessed by measuring the optical density of the supernatant at $532 \mathrm{~nm}$.

\section{Statistical analysis}

Data obtained in this study were subjected to analysis of variance at $\alpha 0.05$ using the general linear model procedure of statistical analysis software. Means were separated with New Duncan's multiple range test of SAS (2011).

The statistical model is as follows:

$\mathrm{Y}_{i j l}=\mu+\mathrm{B}_{i}+\mathrm{e}_{i j l}$

where $Y_{i j l}$ represents the value of serum biochemical parameters and oxidative status measured in the $l$ th animal, $\mu$ is the overall mean for each character, $B_{i}$ is the fixed effect of the $i$ th physiological stages (i.e., dry does, gravid does in the first trimester, gravid does in the second trimester, gravid does in the third trimester, and postpartum does), and $e_{i j l}$ is the random residual effect.

\section{Results}

Serum biochemistry of WAD does of different physiological stages (Table 1) revealed that all serum indices were significantly influenced by the physiological stages of the doe except triglyceride and low-density lipoprotein. Serum glucose of postpartum does and midgestation does was significantly $(P<0.05)$ higher than does in other physiological stages. Total protein of does increases statistically $(P<0.05)$ with the intensity of reproductive stages. The total protein of lactating does have the highest statistical values. Serum albumin of dry does and early gestation does were statistically $(P>0.05)$ similar and were significantly $(P<0.05)$ higher than mid- and late gestation does.

Serum cholesterol and high-density lipoprotein increased progressively with the stage of gestation, with dry does having statistically least values.

Lactating, mid- and late gestation does have significantly $(P<0.05)$ highest cholesterol and high-density lipoprotein values. Aspartate aminotransferase (AST) levels in does increases as gestation progress; dry does have the least values, while lactation does and late gestation does have the highest values. Alkaline phosphatase and urea are significantly $(P<0.05)$ highest in dry does compared to does in gestation and lactation which have statistically similar values. Serum creatinine increases as gestation progress and peaks in lactating does. Serum creatinine of dry does and does at first trimester are statistically $(P>0.05)$ similar and least across the different reproductive stages.

Serum oxidative status of WAD does at different physiological stages is shown in Table 2. Total antioxidant 
Table 1 Serum biochemistry of WAD goats at different physiological stages

\begin{tabular}{|c|c|c|c|c|c|c|c|}
\hline & \multirow[b]{2}{*}{$\begin{array}{l}\text { Dry does, } \\
n=35\end{array}$} & \multicolumn{3}{|l|}{ Gestation } & \multirow[b]{2}{*}{$\begin{array}{l}\text { Lactating does, } \\
n=40\end{array}$} & \multirow[b]{2}{*}{ SEM } & \multirow[b]{2}{*}{$P$ value } \\
\hline & & $\begin{array}{l}\text { First trimester, } \\
n=30\end{array}$ & $\begin{array}{l}\text { Second trimester } \\
n=33\end{array}$ & $\begin{array}{l}\text { Third trimester, } \\
n=31\end{array}$ & & & \\
\hline Glucose (g/L) & $4.94^{b}$ & $4.40^{\mathrm{b}}$ & $13.83^{\mathrm{a}}$ & $3.23^{b}$ & $15.83^{\mathrm{a}}$ & 1.06 & 0.00 \\
\hline Total protein (g/dL) & $26.68^{\mathrm{bc}}$ & $22.60^{c}$ & $49.61^{\mathrm{bc}}$ & $53.70^{\mathrm{b}}$ & $161.76^{\mathrm{a}}$ & 8.56 & 0.00 \\
\hline Albumin (g/L) & $6.24^{\mathrm{a}}$ & $5.98^{\mathrm{a}}$ & $4.94^{\mathrm{b}}$ & $5.06^{b}$ & $5.36^{\mathrm{ab}}$ & 0.15 & 0.01 \\
\hline Triglyceride (mg/dL) & 66.29 & 63.50 & 85.50 & 92.10 & 82.11 & 5.66 & 0.44 \\
\hline Cholesterol (mg/dL) & $47.97^{\mathrm{C}}$ & $80.50^{\mathrm{b}}$ & $104.67^{\mathrm{a}}$ & $109.80^{\mathrm{a}}$ & $100.44^{\mathrm{a}}$ & 4.51 & 0.00 \\
\hline Low density lipoprotein (mg/dL) & 21.05 & 29.18 & 27.57 & 26.78 & 25.02 & 2.69 & 0.87 \\
\hline High density lipoprotein (mg/dL) & $13.76^{c}$ & $38.63^{b}$ & $59.89^{a}$ & $64.60^{a}$ & $57.44^{a}$ & 3.21 & 0.00 \\
\hline Aspartate aminotransferase (u/L) & $28.11^{d}$ & $36.34^{c}$ & $43.69^{\mathrm{b}}$ & $58.86^{\mathrm{a}}$ & $51.06^{\mathrm{ab}}$ & 2.36 & 0.00 \\
\hline Alkaline phosphatase (u/L) & $1244.34^{\mathrm{a}}$ & $201.63^{b}$ & $167.78^{b}$ & $190.90^{b}$ & $212.00^{b}$ & 117.19 & 0.00 \\
\hline Alanine aminotransferase ( $u / L)$ & $11.39^{b}$ & $14.42^{b}$ & $17.13^{\mathrm{ab}}$ & $22.71^{\mathrm{a}}$ & $19.84^{\mathrm{a}}$ & 0.87 & 0.00 \\
\hline Creatinine (mg/dL) & $59.84^{\mathrm{b}}$ & $54.24^{b}$ & $136.85^{\mathrm{ab}}$ & $334.09^{a b}$ & $536.74^{\mathrm{a}}$ & 70.03 & 0.13 \\
\hline Urea (mg/dL) & $97.75^{\mathrm{a}}$ & $14.15^{b}$ & $15.66^{\mathrm{b}}$ & $14.85^{\mathrm{b}}$ & $16.42^{b}$ & 8.11 & 0.00 \\
\hline
\end{tabular}

Different superscript letters denote statistically significant differences at $P \leq 0.05$. SEM standard error mean

activities of dry does are statistically $(P>0.05)$ similar to early and mid-gestation does, while late gestation does and postpartum does have significantly $(P>0.05)$ least total antioxidant activities across the physiological stages. Serum lipid peroxidation of does increases with stages of pregnancy and significantly $(P<0.05)$ peaks in late prepartum and postpartum does. Superoxide dismutase activity of early gestation does is significantly $(P>0.05)$ higher than other physiological stages, which have statistically similar values. Glutathione peroxidase activity and catalase of early gestation does and dry does are significantly $(P<$ $0.05)$ higher than other physiological stages. The activity of glutathione peroxidase and catalase decreases as gestation progress, and significantly $(P<0.05)$ least values are obtained in postpartum does.

\section{Discussion}

The physiological stage-dependent increase in glucose could be due to the considerable glucose requirements for nutrition in pregnant animals (Parr et al. 1984) evidently at postpartum for lactogenesis. Evidence of low glucose concentration at third trimester is linked with cases of pregnancy toxaemia observed in does (Al-Qudah 2011). Steel and Leng (1973) observed that irreversible loss of glucose increased progressively with the stage of gestation in sheep fed to appetite and maintained on a constant intake throughout pregnancy (Waziri et al. 2010).

A similar trend that serum glucose concentration was higher in early lactation compared to late pregnancy in WAD goats was reported by Radin et al. (2015) for Saanen goats. Protein is an essential component of cells, and during gestation, the protein is required for fetal growth and maintenance of the dam; this accounts for the increase in serum total protein as gestational age. Due to lactation requirements, udder uses a large amount of protein for milk production during lactation (Quiroz-Rocha et al., 2009); this explains the increased total protein levels in WAD does postpartum. Albumin is non-enzymatic protein antioxidants that are primarily found in plasma, are mainly represented by sulfhydryl, and are considered a significant element of the extracellular antioxidant defense system against oxidative stress (Urban-Chmiel 2006). This suggests that the animals at

Table 2 Serum oxidative stress markers of WAD goats at different physiological stages

\begin{tabular}{|c|c|c|c|c|c|c|c|}
\hline & \multirow[b]{2}{*}{$\begin{array}{l}\text { Dry does, } \\
n=35\end{array}$} & \multicolumn{3}{|l|}{ Gestation } & \multirow[b]{2}{*}{$\begin{array}{l}\text { Lactating does, } \\
n=40\end{array}$} & \multirow[b]{2}{*}{ SEM } & \multirow[b]{2}{*}{$P$ value } \\
\hline & & $\begin{array}{l}\text { First trimester, } \\
n=30\end{array}$ & $\begin{array}{l}\text { Second trimester, } \\
n=33\end{array}$ & $\begin{array}{l}\text { Third trimester, } \\
n=31\end{array}$ & & & \\
\hline Total antioxidant activity (mmol/L) & $10.34^{\mathrm{ab}}$ & $9.61^{b}$ & $14.77^{\mathrm{a}}$ & $2.71^{c}$ & $1.67^{c}$ & 1.98 & 0.03 \\
\hline Lipid peroxidation ( $\times 10^{-3} \mathrm{MDA} / \mathrm{mg}$ protein) & $0.13^{b}$ & $0.04^{c}$ & $0.11^{\mathrm{b}}$ & $0.32^{\mathrm{a}}$ & $0.44^{\mathrm{a}}$ & 0.00 & 0.00 \\
\hline Glutathione peroxidase ( $\mu \mathrm{g} \mathrm{GSH/min/mg} \mathrm{protein)}$ & $10.40^{\mathrm{a}}$ & $13.10^{\mathrm{a}}$ & $4.48^{\mathrm{b}}$ & $4.67^{b}$ & $1.70^{c}$ & 0.81 & 0.00 \\
\hline Catalase ( $\mathrm{nm} \mathrm{H} \mathrm{H}_{2} / \mathrm{min} / \mathrm{mg}$ protein) & $33.58^{\mathrm{a}}$ & $42.27^{\mathrm{a}}$ & $14.63^{b}$ & $15.27^{\mathrm{b}}$ & $5.56^{\mathrm{C}}$ & 2.62 & 0.00 \\
\hline Superoxide dismutase ( $\mathrm{U} / \mathrm{min} / \mathrm{mg}$ protein) & $0.02^{b}$ & $0.28^{\mathrm{a}}$ & $0.02^{b}$ & $0.01^{\mathrm{b}}$ & $0.01^{b}$ & 0.06 & 0.02 \\
\hline
\end{tabular}

Different superscript letters denote statistically significant differences at $P \leq 0.05$. SEM standard error mean 
mid- to late gestation are exposed to oxidative stress. Plasma albumin levels are also decreased in dairy goats during summer and during the peripartum period in dairy goats which further indicates that goats were exposed to oxidative stress ( $\mathrm{Di}$ Trana et al. 2006). This finding is quite relevant considering that albumin is part of the antioxidant pool, and it is a free radical scavenger (Halliwell 1988). Studies in dairy cows have confirmed the antioxidant role played by albumin particularly near calving when animals usually do not receive any vitamin/mineral supplementation (Castillo et al. 2005). Similarly, udder uses a large amount of protein for milk production during lactation (Quiroz-Rocha et al. 2009) which could explain the increased albumin levels of postpartum WAD does as obtained in this study and Radin et al. (2015) in Saanen goats.

Serum cholesterol and high-density lipoprotein increased progressively with the stage of gestation, with dry does having statistically least values. Lactating, mid-, and late gestation does have significantly $(P<0.05)$ highest cholesterol and high-density lipoprotein values. This is similar to the report of Waziri et al. (2010) that cholesterol concentration of Sahel goats increased as pregnancy advanced up to 20 weeks. Tietz (1994) attributed the increase in cholesterol to the physiological alteration of endocrine function. The range of values obtained was comparable to other authors, Kamalu et al. (1988) in WAD goats and Waziri et al. (2010) in Sahel goats.

Aspartate aminotransferase (AST) levels in does increase as gestation progress; dry does have the least values while lactation does and late gestation does have the highest values. Serum creatinine increases as gestation progress and peaks in lactating does. Serum creatinine of dry does and does at first trimester are similar and least across the different reproductive stages. The range of values of urea, creatinine, AST, ALT, and alkaline phosphatase was in agreement with other authors (Ihejirika et al. 2017 and Uwaeziozi et al. 2017). This is an indication that during stages of pregnancy and postpartum, the kidneys (urea and creatinine) and the liver (AST and ALT) were not clinically affected.

The antioxidant defense of does decreases as gestation progress up to lactation and was accompanied by increased generation of pro-oxidants, thus predispose the animals to oxidative stress. In dairy goats, SOD activity is decreased during the postpartum period probably as a consequence of lower peroxide generation as testified by the decrease in reactive oxygen molecule (ROM) concentrations (Celi 2010). Because SOD activity increases $\mathrm{H}_{2} \mathrm{O}_{2}$ production, protection from reactive oxygen would only be given by a simultaneous increase in catalase and GPx activities and availability of glutathione (Celi 2011a) and vice-versa. This is in accordance with the result of this study, as a decrease in SOD is accompanied by a resultant decline in glutathione peroxidase and catalase activities as the does approach parturition and lactation. Similarly, studies in dairy goats have shown that blood GPx activity is decreased during the postpartum period, suggesting that goats may have experienced some degree of oxidative stress (Celi et al. 2008). Similarly, Pilarczyk et al. (2012) reported that serum GPx activity varied according to the physiological status of cow. However, contrary to the report of Pilarczyk et al. (2012) that plasma GPx activity in prepartum (dry) cows was lower than that observed during the first month postpartum, the reverse is the case.

The observed decline in antioxidant enzyme activity from mid-gestation to lactation could be due to depletion of the antioxidants and/or mobilization for more physiological demand such as immunity. As suggested by Castillo et al. (2005) that the observed decrease in antioxidant enzymes' activity as lactation progressed probably happened due to the depletion of antioxidants by milk. However, studies in dairy cows have confirmed the antioxidant role played by albumin particularly near calving when animals usually do not receive any vita$\mathrm{min} /$ mineral supplementation (Castillo et al. 2005). The albumin activity increased apparently from the midgestation through to lactation. A sharp significant decline in the albumin activity occurs at mid-gestation compared with early gestation and dry does. That could counteract the adverse effect of the accumulated low antioxidant enzyme defense as parturition and lactation approach. The result revealed that total antioxidant defense is higher at early and mid-gestation and dry does, through low lipid peroxidation and high antioxidant production. Both reactive oxygen species and antioxidants have major physiological roles in all reproductive processes. This is similar to Karapehlivan et al. (2012) that antioxidant potential reduced and oxidative stress increased in early lactation goats. And the depletion of critical antioxidant defense components in tissues may predispose to metabolic changes which originated from oxidative stress. As the peak of the reproductive process is experienced at late prepartum and postpartum, the generation of reactive oxygen species increases with the physiological demand for the sustenance of fetus/kid and milk production. During the peripartum period, due to characteristics, metabolic changes, reactive oxygen, and nitrogen metabolites are produced in excess (Celi 2011b). At late prepartum/parturition, early lactation is the period of considerable energy deficit and severe metabolic changes, especially in terms of lipid and protein metabolism. Van Saum et al. (1989) report that in the body of the late prepartum female, the uterus is given priority to other organs in the distribution of some substances, according to the homeorhesis principle. The increase in metabolism is paralleled by 
the modification of energy balance and increased oxygen consumption, and thus increased ROS production, largely due to the fact that most tissues use fatty acids liberated from depot fat as the primary source of energy (Adela et al. 2006). The physiological stress associated with rapid differentiation of secretory parenchyma, intense mammary gland growth, and the onset of colostrum and milk biosynthesis and secretion also are not without significance (Sharma et al. 2011). It is thought that the increased metabolic rate after parturition may be responsible for the increase in respiratory electron transfer and production of reactive oxygen metabolites. When production of oxidants is faster than they can be neutralized by antioxidants, it may result in oxidative stress (Jimoh 2016). This is supported by claims that lipid peroxidation associated with oxidative stress is involved in the development and complications of pregnancy toxemia in ewes and cows (Al-Qudah 2011). The correlation of the antioxidant activity with progesterone levels indicates that antioxidative mechanisms are activated to cope with steroidogenesis-dependent oxyradical formation in the bovine corpus luteum (Rapaport et al. 1998). This corroborates claims that antioxidant defense in the female reproductive tract may have some regulatory role in fertility (Jean-François and Marc-André 2001).

Due to the climatic condition of the region, other factors and stressors can aggravate the events that lead to oxidative stress. Heat stress which is prevalent in tropics and seasonal factors (Di Trana et al., 2006) induces systemic changes in redox status in the maternal body, and the resultant increase in oxidative stress in the oviduct is possibly involved in the heat stress-induced early embryonic death (Matsuzuka et al. 2005).

The dietary and tissue balance of antioxidant nutrients is important in protecting tissues against free radical accumulation and damage. Vitamins and trace minerals have dual effects such as control of metabolic pathways or gene expression and ROS trapping activity. Their deficiency may induce high rates of ROS production resulting in different disorders of gestation (Aurousseau et al. 2006), and lead to different kinds of stress (McDowell et al., 2007). Vitamin E-selenium injections given before mating significantly increased the incidence of oestrus response, fecundity rates, and lamb body weight at 60 days of age in ewes (Koyuncu and Yerlikaya 2007). The antioxidant function enhances immunity by maintaining the structural and functional integrity of the important immune cells; elsewise, compromised immune system will result in reduced animal production efficiency through increased susceptibility to diseases, thereby leading to increased animal morbidity and mortality (McDowell 2002). Recently, the detection of free radical damage and the protection against it have become very important in animal production/reproduction; this is because the level of lipid peroxidation and antioxidant status give complementary information about the metabolic status of the animal rather than metabolic parameters alone (Castillo et al. 2003).

This study gives reference values for both oxidants and antioxidants in West African dwarf goats at different physiological stages, as well as the level of oxidative stress. It is essential that while focusing on the nutritional components for improving production/reproduction, the antioxidant status of the ruminants must be maintained at the proper times (during growth, pregnancy, deficiency, or under stress), in addition to energy, protein, and mineral balance to optimize the ruminant production/reproduction (Nayyar and Jindal 2010). This suggests that evaluation of the oxidative stress, i.e., lipid peroxidation level and total antioxidant activity (enzymatic and non-enzymatic), is necessary for addition to the metabolic profile while conducting physiological, biochemical, and nutritional studies in ruminants. Further studies should focus on the effect of antioxidant supplements of does at late gestation and postpartum on oxidative stability of reproductive tissues and organs as well as fetus up to kid.

\section{Conclusion}

This study has revealed that West African dwarf does in third trimester and lactation displayed oxidative stress due to intense metabolism during the physiological states. This is revealed by the metabolic profile and oxidative status of the does assessed. It is recommended that antioxidant fortification/supplementation should be employed during late gestation and lactation as management practice to combat the oxidative stress observed in West African dwarf goats.

\section{Abbreviations}

ALT: Alanine aminotransferase; AST: Aspartate aminotransferase; BCS: Body condition score; GPx: Glutathione peroxidase activity; MDA: Malondialdehyde; PPR: Peste des petits ruminants; ROM: Reactive oxygen molecules; SOD: Superoxide dismutase; WAD: West African dwarf

\section{Acknowledgements}

The authors are grateful to the management of the livestock farm for their assistance in providing animals and logistic support for this work.

\section{Authors' contributions}

The study was designed by JOA and IUGD and carried out by IUGD and OAO contributed to collection and analysis of the sample. JOA wrote the experimental protocol, assay procedure, and the first manuscript draft. IUGD carried out the biochemical and statistical analysis. All authors read and approved the final manuscript.

\section{Authors' information}

Jimoh, Olatunji Abubakar Ph.D. (Registered Animal Scientist; Nigerian Institute of Animal Science)

Lecturer and consultant

Animal Physiology and Bioclimatology

Department of Agricultural Technology, Federal Polytechnic Ado Ekiti, Ekiti State, Nigeria

Email: abubakarjimoh2011@gmail.com

Ojo, Olayinka Abosede Ph.D.

Lecturer 
Department of Animal Production, Fisheries and Aquaculture

Kwara State University

Molete, Kwara State, Nigeria

Ihejirika Uchechi Daureen Gift Ph.D

Doctoral fellow and research Assistant

Animal Physiology and Bioclimatology Unit

Department of Animal Science

University of Ibadan, Oyo State, Nigeria

\section{Funding}

The research outcome presented in this article was jointly funded by the authors. This research did not receive any specific grant from any funding agency in the public, commercial, or not-for-profit sector.

\section{Availability of data and materials}

The datasets used and/or analyzed during the current study are available from the corresponding author on reasonable request.

\section{Ethics approval and consent to participate}

The study was undertaken with approval from the institutional ethics committee for care and use of animal for research of the host institution.

\section{Consent for publication}

Not applicable

\section{Competing interests}

The authors declare that they have no competing interests.

\section{Author details}

${ }^{1}$ Animal Production Unit, Department of Agricultural Technology, Federal Polytechnic Ado-Ekiti, Ado Ekiti, Ekiti State, Nigeria. ${ }^{2}$ Animal Physiology and Bioclimatology Unit, Department of Animal Science, University of Ibadan, Ibadan, Oyo State, Nigeria. ${ }^{3}$ Department of Animal Production, Fisheries and Aquaculture, Kwara State University, Malete, Kwara State, Nigeria.

Received: 7 May 2019 Accepted: 30 October 2019

Published online: 16 December 2019

\section{References}

Adela P, Zinveliu D, Pop RA, Andrei S, Kiss E (2006) Antioxidant status in dairy cows during lactation. Bull USAMV-CN 63:130-135

Adeloye AA (1998) The Nigerian Small Ruminant Species. Corporate Office Max. Ilorin, Nigeria. pp. 7-8.

Al-Qudah KM (2011) Oxidant and antioxidant profile of hyperketonemic ewes affected by pregnancy toxaemia. Vet Clin Pathol 40(1):60-65

Aurousseau B, Gruffat D, Durand D (2006) Gestation linked radical oxygen species fluxes and vitamins and trace mineral deficiencies in the ruminant. Reprod Nutr Dev 46:601-620

Beers RF, Sizer IW (1952) A spectrophotometric method for measuring the breakdown of hydrogen peroxide by catalase. J Biol Chem 195:133-140

Behrman HR, Kodaman PH, Preston SL, Gao S (2001) Oxidative stress and the ovary. J. Soc. Gynecol. Investig., (1 Suppl. Proceedings), 8, 40-42..

Castillo C, Hernandez J, Bravo A, Lopez-Alonso M, Pereira V, Benedito JL (2005) Oxidative status during late pregnancy and early lactation in dairy cows. The Veterinary Journal 169:286-292

Castillo C, Hernández J, López-Alonso M, Miranda M, Benedito JL (2003) Values of plasma lipid hydroperoxides and total antioxidant status in healthy dairy cows: preliminary observations. Arch Tierz 46:227-233

Celi $P$ (2010) The role of oxidative stress in small ruminants' health and production. R Bras Zootec 39:348-363

Celi $\mathrm{P}$ (2011a) Biomarkers of oxidative stress in ruminant medicine. Immunopharmacol Toxicol 33:233-240

Celi P (2011b) Oxidative stress in ruminants. In. Studies on Veterinary Medicine, L Mandelker and P Vajdovich (eds.), Oxidative stress in applied basic research and clinical practice 5, 71-73. DOI https://doi.org/10.1007/ 978-1-61779-071-3_13.

Celi P, Di Trana A, Quaranta A (2008) Metabolic profile and oxidative status in goats during the peripartum period. Aust J Exper Agric 48:1004-1008

Di Trana A, Celi P, Claps S, Fedele V, Rubino R (2006) The effect of hot season and nutrition on the oxidative status and metabolic profile in dairy goats during mid lactation. Anim Sci 82:717-722
Halliwell B (1988) Albumin - an important extracellular antioxidant. Biochem Pharmacol 37:569-571

Ihejirika UGD, Adenekan OO, Jimoh OA, Jack AA, Uwaeziozi UC (2017) Serum biochemistry and oxidative stress indicators in West African dwarf goats under semi-intensive management system. Nig J Anim Prod 44(4):110-117

Jack AA, Jimoh OA, Ihejirika UG, Uwaeziozi UC, Adenekan OO (2016) Assessment of oxidative stress indicators of West African Dwarf sheep under semiintensive management system. Nig J Anim Prod 43(2):78-83

Jean-François B, Marc-André S (2001) Levels of enzymatic antioxidant defenses are modulated in the bovine oviductal fluid during the estrous cycle. 34th annual meeting of society for the study of reproduction. Jul. 28-Aug. 1, University of Ottawa. Abstract No. 562 Parent Session: Female Reproductive System (uterus/oviduct).

Jimoh OA (2019) Oxidative stress indicators of rabbit breeds in Ibadan, Southwest Nigeria. Bull Natl Res Cen 43(62):1-7 https:/doi.org/10.1186/s42269-019-0104-z

Jimoh OA, Adenekan OO, Jack AA, Uwaeziozi UC, Ihejirika UG (2018) Physiological variations and oxidative status in West African dwarf male sheep and goat in semi-intensive management system. An Res Int 15(1):2898-2905

Jimoh OA, Ewuola EO (2018) Thermophysiological traits in four exotic breeds of rabbit at least temperature-humidity index in humid tropics. J Basic Appl Zool 79(18), 31-39. https://doi.org/https://doi.org/10.1186/s41936-018-0031-9

Kamalu TN, Shetty SN, Nair SG (1988) Biochemistry of blood of West African Dwarf goats. Trop Vet 6:2-5

Karapehlivan M, Kaya I, Sağ A, Akin S, Özcan A (2012) Effects of early and late lactation period on plasma oxidant/antioxidant balance of goats. Kafkas Univ Vet Fak Derg 19 (3), 529-533, 2013 DOl: https://doi.org/10.9775/kvfd.2012.8315.

Koracevic D, Koracevic G, Djordjevic V, Andrejevic S, Cosic V (2001) Method for the measurement of antioxidant activity in human fluids. J Clin Pathol 54: 356-361

Koyuncu M, Yerlikaya H (2007) Effect of selenium-vitamin E injections of ewes on reproduction and growth of their lambs. S Afr J Anim Sci 37:233-236

Luck MR, Jeyaseelan I, Scholes RA (1995) Minireview: ascorbic acid and fertility. Biol Reprod 52:262-266

Matsuzuka T, Ozawa M, Nakamura A, Ushitani A, Hirabayashi M, Kanai Y (2005) Effects of heat stress on the redox status in the oviduct and early embryonic development in mice. J Reprod Dev 51:281-287

McDowell LR (2002) Recent advances in minerals and vitamins on nutrition of lactating cows. Pak J Nutr 1:8-19

McDowell LR, Wilkinson N, Madison R, Felix T (2007) Vitamins and minerals functioning as antioxidants with supplementation considerations. Florida Ruminant Nutrition Symposium. Best Western Gateway Grand. Gainesville, FL, 30-31 January. http://dairy.ifas.ufl.edu/files/ rns/2007/Mcdowell.pdf.

Nayyar S, Jindal R (2010) Essentiality of antioxidant vitamins for ruminants in relation to stress and reproduction. Iran J Vet Res 11(1):1-9

Ockert K (2015) Body condition scoring in goats. Michigan State University Extension. Webpage www.mse.edu. Last web soyrce www.canr.msu.edu/ news/body-condition-scoring-in-goats.

Ohkawa H, Ohishi N, Yagi K (1979) Assay for lipid peroxides in animal tissues by thiobarbituric acid reaction. Anal Biochem 95:351-358

Parr RA, Cambell IP, Cahill LP, Bindon BM, Piper LR (1984) Flock glucose profiles and productivity in Boorola and random bred control merino ewes. Proc Aust Soc Anim Prod 15:517-520

Pilarczyk B, Jankowiak D, Tomza-Marciniak A, Pilarczyk R, Sablik P, Drozd R, Tylkowska A, Skólmowska M (2012) Selenium concentration and glutathione peroxidase (GSH-Px) activity in serum of cows at different stages of lactation. Biol Trace Elem Res 147:91-96. https://doi.org/10.1007/s12011-011-9271-y

Quiroz-Rocha G, Leblanc SJ, Duffield TF, Wood D, Leslie KE, Jacobs RM (2009) Reference limits for biochemical and haematological analytes of dairy cows one week before and one week after parturition. Can Vet J 50:383-391

Radin L, Simpraga M, Vince S, Kostelic A, Milinkovic-Tur S (2015) Metabolic and oxidative status of Saanen goats of different parity during the peripartum period. J Dairy Res 82:426-433

Rapaport R, Sklan D, Wolfenson D, ShahamAlbalancy A, Hanukoglu I (1998) Antioxidant capacity is correlated with steroidogenic status of the corpus luteum during the bovine estrous cycle. Biochim Biophys Acta 1380:133-140

Rotruck JT, Pope AL, Ganther HE, Swanson AB, Hafeman DC, Hoekstra WG (1973) Selenium: biochemical roles as a component of glutathione peroxidase. Science 179:588-590

Ruder EH, Hartman TJ, Blumberg J, Goldman MB (2008) Oxidative stress and antioxidants: exposure and impact on female fertility. Hum Reprod Update $14: 345-357$ 
Sharma N, Singh N, Singh O, Pandey V, Verma P (2011) Oxidative stress and antioxidant status during transition period in dairy cows. Asian Aust J Anim Sci 24:479-484

Soon YY, Tan BKH (2002) Evaluation of the hypoglycemic and anti-oxidant activities of Morinda officinalis in streptozotocininduced diabetic rats. Singapore Med J 43:77-85

SAS Statistical Analysis Software (2011) Statiscal Analysis Systems Propriety Software Release. SAS Institute Inc.,Car.

Steel JW, Leng RA (1973) Effects of plane of nutrition and pregnancy on gluconeogenesis in sheep: kinetics of glucose metabolism. Brit Vet J Nutrit 30:451-473

Tietz NW (1994) Lipid metabolism-Fundamentals of Clinical Chemistry, 2nd edn. Balliere Tindall, London, pp 234-240

Urban-Chmiel R (2006) The influence of transport stress on oxidative stress parameters in bovine leukocytes. Slovenian Veterinary Research Vol.43 No. Supplement 10 pp.241-244.

Uwaeziozi UC, Jimoh OA, Ihejirika UGD, Jack AA, Adenekan OO (2017)

Physiological variations between female West African dwarf Goat and Sheep. Int J BioSci Agric Technol 8(6):42-50

Van Saum RJ, Herdt TH, Stowe HD (1989) Maternal and fetal selenium in neonatal calves. J Dairy Sci 67:1128-1137

Waziri MA, Ribadu AY, Sivachelvan N, Waziri MA, Ribadu AY, Sivachelvan N (2010) Changes in the serum proteins, hematological and some serum biochemical profiles in the gestation period in the Sahel goats Sahel goats. Vet Arhiv 80: $215-224$

\section{Publisher's Note}

Springer Nature remains neutral with regard to jurisdictional claims in published maps and institutional affiliations.

\section{Submit your manuscript to a SpringerOpen ${ }^{\circ}$ journal and benefit from:}

- Convenient online submission

- Rigorous peer review

- Open access: articles freely available online

- High visibility within the field

- Retaining the copyright to your article

Submit your next manuscript at $\boldsymbol{\nabla}$ springeropen.com 